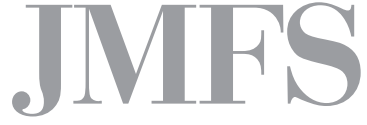

Journal of Management and Financial Sciences
Volume XII

Issue 37 (June 2019

pp. $25-46$

Warsaw School of Economics

Collegium of Management and Finance

Andrzej Tokarski

Institute of Finance

Faculty of Finance and Management

WSB University in Torun

Maciej Tokarski

Institute of Finance

Faculty of Finance and Management

WSB University in Torun

\title{
Restructuring proceedings as a positive effect of implementing the instruments of the New Chance Policy in the Polish economy in the years 2016-2018
}

ABSTRACT

You can respond to a business crisis in two ways: either by saving it (restructuring or remodelling the company and limiting, at least temporarily, creditor rights, while preserving the jobs and assets of the restructured entrepreneur) or by liquidating it (by realization of the estate and thus liquidation of the economic entity with a partial satisfaction of creditors and simultaneous return of tangible assets to trading). Thus, both liquidation and reorganization are possible in most countries.

The problem of the accuracy of choice between the liquidation of an enterprise and its restructuring is one of the main topics of interest for practitioners and theorists dealing with the bankruptcy of enterprises. The decision to restructure constitutes an alternative to declaring an enterprise bankrupt. The aim of the article is to present kinds of restructuring proceedings, taking into account their characteristics, advantages and disadvantages, benefits and threats resulting from the multitude of restructuring proceedings including an analysis and statistics concerning the analysed phenomenon in the Polish economy in the years 2016-2018. 
Keywords: restructuring proceedings, restructuring of enterprises, Second Chance Policy, New Chance Policy, restructuring law

JEL Classification Codes: G33, G34, M41

\section{Introduction}

You can respond to a business crisis in two ways: either by saving it (restructuring or remodelling the company and limiting, at least temporarily, creditor rights, while preserving the jobs and assets of the restructured entrepreneur) or by liquidating it (by realization of the estate and thus liquidation of the economic entity with a partial satisfaction of creditors and simultaneous return of tangible assets to trading). Thus, both liquidation and reorganization are possible in most countries [Altman, Hotchkiss, 2007, p. 22].

In both cases there should be a positive effect for the economy, i.e. either the company can be saved, and jobs can be kept or the entity which was no longer capable of conducting its business activities in a manner safe for other market participants, will be eliminated from the market and its liquefied assets will be utilized by other market participants.

Comparing bankruptcy statistics in Poland with other EU member countries clearly indicates that bankruptcy proceedings in Poland are used relatively rarely, and insolvent enterprises usually disappear from the market by an informal liquidation [ [Bankruptcy and Restructuring, 2017, p. 6]. Such a state of affairs is unfavourable to creditors and for the security of trading, because in such cases insolvency law mechanisms which protect them are not used [Evaluation, 2014, p. 1].

Public perception of a particular legal regulation and proceedings of restructuring is of crucial importance for conducting successful restructuring of an enterprise. Practice shows that declaring the debtor's bankruptcy itself repeatedly excludes any possibility of conducting a successful restructuring, whether it is bankruptcy with the possibility of concluding an arrangement or liquidation bankruptcy. Associating bankruptcy with ending business activity, insolvency and not being able to recover debts is so strong that in many cases creditors do not want to negotiate with the debtor.

Despite the European Commission's recommendations in relation to adopting the second chance policy by the Member States, in the Polish economy in the years 2003-2015, the scope of implementing so called the Second Chance Policy recommended by the EU was limited [Mączyńska et al., 2015, p. 193]. In the analysed period of time, Poland lacked a developed strategy of implementing such a policy, neither were those whom such a policy concerned precisely defined despite information included in the documents of the Ministry of Economy [Kowalewska, 2011, p. 177].

The aim of the article is to present types of restructuring proceedings taking into account their characteristics, classification, advantages and disadvantages, benefits and threats resulting 
from the multitude of restructuring proceedings, including an analysis and statistics concerning the analysed phenomenon in the Polish economy in the years 2016-2018. ${ }^{1}$

A descriptive analysis, a review of legislation and of statistics concerning functioning of the institution of corporate bankruptcy and of restructuring proceedings in Poland and an analysis of source literature are the methods used in the article.

\section{The Second Chance Policy of the European Union: the determinants of the New Chance Policy in the Polish economy}

The decision to conduct restructuring constitutes an alternative to declaring an enterprise bankrupt. It must be a conscious decision, because it opens the way for entrepreneurs to continue activity without harming creditors. The majority of them, mainly suppliers and employees, are not interested in liquidating an economic entity [Kowalak, 2017, p. 177].

An approach to conducting economic activity has changed in recent years. Societies have understood that financial problems experienced by entrepreneurs do not always result from managers' ill will. Many of them should be given a second chance supported by a country's legal system [A. Tokarski, M. Tokarski, 2018, pp. 40-41]. Such help needs to be deliberate and supported with methods that will make it possible to assess whether the decision to restructure is correct.

The Second Chance Policy involves full return of entrepreneurs experiencing financial difficulties or insolvency to business trading. In order to achieve this objective, restructuring instruments as well as liquidating instruments not stigmatising entrepreneurs, i.e. not discouraging potential counterparties and other transaction parties, are necessary [Rekomendacje, 2012, p. 27].

Since 2001 the European Commission has been undertaking actions aiming at starting a new policy which would solve the problem of threatened enterprises and negative effects of their bankruptcies [Mączyńska et al., 2010, pp. 433-434]. Such actions would involve collecting data on legal and social consequences of business failures, facilitating identification and dissemination of good practices and working on early warning tools as a means of reducing the stigma of business failure [Piasecki, 2012, p. 24]. Those activities helped to initiate reforms in the whole European Union. Within the Stigma of Failure and Early Warning project, an early warning tool has been developed for small and medium-sized enterprises, which enables preliminary assessment of their situation and the threat of a crisis situation and bankruptcy [Mączyńska et al., 2008, p. 13].

1 At the beginning of 2016 a new Restructuring Law came into force in Poland, at the same time the existing Bankruptcy and Reorganisation Law was amended. Consequently, two separate laws regulating two types of proceedings against economic entities experiencing problems with settling liabilities have been in force since the beginning of 2016: Bankruptcy Law of $15^{\text {th }}$ May 2015 (Journal of Laws of 2015, item 233) (hereinafter referred to as 'BL') and Restructuring Law of $15^{\text {th }}$ May 2015 (Journal of Laws of 2015 item 978) (hereinafter referred to as 'RL') 
On $25^{\text {th }}$ June 2008 the European Commission published a communication entitled Think Small First. In the Small Business Act for Europe, among the ten main principles for the policies of the European Union and the Member States in relation to the SME sector principle number 2 can be found which ensures that honest entrepreneurs whose entrepreneurship has been declared bankrupt are quickly given a second chance. The European Commission requested the Member States to do the following [Wieczerzyńska, 2015, p. 59]:

- promote a positive attitude of the society towards entrepreneurs returning to the market;

- enable finishing all legal procedures leading to bankruptcy within one year in the case of bankruptcy not resulting from fraud;

- ensure identical conditions of economic activity for both returning and new entrepreneurs. In November 2016, the European Commission proposed a package of European legislation concerning enterprises threatened with bankruptcy. The suggested directive focuses on three elements:

- common rules for a framework for restructuring at an early stage, which helps enterprises to continue their activity and preserve jobs;

- provisions allowing entrepreneurs to take a second chance as they will be able to relieve themselves from liabilities within a period of up to three years;

- allocating resources to Member States to increase the efficiency of the procedures in connection with bankruptcy, restructuring and relieving from liabilities.

It was not until $22^{\text {nd }}$ July 2014 that the Council of Ministers adopted the New Chance Policy document, which provides many instruments for limiting the risk of liquidation and efficient conduct of corporate bankruptcy.

In the opinion of the Ministry of Economy, in accordance with the assumptions of the New Chance Policy, more emphasis should be placed on popularising the process of corporate reorganisation (Polityka nowej szansy, 2015, p. 6). It implies the necessity to decide on initiating recovery proceedings first, then an arrangement procedure and only in the case of the lack of reasons for starting restructuring - liquidation proceedings. One of the main objectives of proceedings should be continuing the activity of functioning economic entities in all those cases where it is consistent with rational management. It gives the chance to maintain jobs, among others. The guideline for keeping those enterprises (or their organised parts) which have made efforts to restructure and adjust to the changed economic environment in business should result directly from the amended legal regulations.

The main aim of the New Chance Policy in the Polish economy is to counteract corporate bankruptcy and facilitate restarting of economic activity. This objective shall be achieved with the support of the following activities:

- preventing crisis situations in enterprises (early warning systems);

- limiting the risk of premature liquidation of enterprises (non-judicial and judicial forms of repair and restructuring);

- an orderly winding down of enterprises (judicial forms of restructuring and liquidation);

- supporting restarting of economic activity - so called 'new start'. 
The model solution adopted in the amendment of the bankruptcy law against the background of global trends is based on three pillars, which are best defined by the government concept of the Second Chance Policy. The proposed model assumes existence of preventive instruments, that is monitoring the current state of an enterprise or risk assessment. Corrective functions are correlated with restructuring and they base on cooperation between participants following the way that aims at ending a given crisis and ensuring maintaining functioning of an enterprise. The third, equally important element is a new start of an enterprise after changes as a stage of bankruptcy proceedings [Miodek, Speer, 2015, p. 57].

Bankruptcy procedures operating smoothly should constitute an embodiment of the Second Chance law implementation that should ensure the following [Morawska, Staszkiewicz, 2016, p. 48]:

- a fast return of means of production in the case of underperformance of a business venture;

- redemption of debts incurred during conducting business activity by honest entrepreneurs declared bankrupt;

- procedures that enable restructuring at an early stage, in the situation of temporary difficulties, in order to avoid insolvency.

Another activity within the frames of the New Chance Policy, conducted by the Polish Agency for Enterprise Development and Family Businesses Foundation, is the Early Warning Poland project started in 2017, whose aim is to support entrepreneurs in overcoming difficult situations. It will build upon individual work of an entrepreneur with a consultant on identifying the problem, developing a diagnosis and further on working with a mentor or advisor who will help to conduct restructuring. The programme was presented on $7^{\text {th }}$ December 2016 at the Early Warning Europe conference organised by the Polish Agency for Enterprise Development (PAED) with the Ministry of Development under the New Chance Policy programme [Ropega, 2017, p. 280]. The discussion on the concept of the programme and its tools refers both to good practices and experiences of the authors of the programme, and to the specificity of the Polish support system. It should be emphasised that including the biggest possible number of groups of Polish entrepreneurs is a crucial element of a real impact of the programme on educating entrepreneurs in the scope of preventing economic failures and facilitating return of an entrepreneur (former entrepreneur) to conducting another economic activity.

\section{Legal regulations in the area of bankruptcy and restructuring in the Polish economy}

At the beginning of 2016, the Restructuring Law came into force, also the previously existing Bankruptcy and Reorganisation Law was amended. As a result, two separate laws regulating two types of proceedings for economic entities experiencing problems with settling liabilities have been in force [Banasik, Morawska, 2016, p. 25]: 
- Bankruptcy Law of $15^{\text {th }}$ May 2015 (Journal of Laws of 2015, item 233) (hereinafter referred to as “BL");

- Restructuring Law of $15^{\text {th }}$ May 2015 (Journal of Laws of 2015 item 978) (hereinafter referred to as "RL").

To put it simply, it can be said that restructuring law aims at saving and bankruptcy law at liquidation of a debtor's enterprise [Hrycaj, 2015, p. 5].

The main objective of the introduced changes was to eliminate stigmatisation of a debtor when bankruptcy proceedings were initiated, even with the arrangement option, and the need to eliminate the threat of announcing liquidation bankruptcy by court following a request of a debtor who, however, demanded restructuring within the framework of bankruptcy in the arrangement option [Hrobiowski, 2016, p. 97].

Separating bankruptcy proceedings, aiming at liquidation of assets, and restructuring proceedings, whose objective is to maintain an enterprise's activities, constitutes the main change [Prawo, 2011, p. 132]. The separation created a clear framework for both sides, which in its construction is similar to solutions from for instance the United States (Chapter 7 - bankruptcy and Chapter 11 - restructuring) [White, 1989, p. 56].

\section{Diagram 1. Bankruptcy and restructuring proceedings}

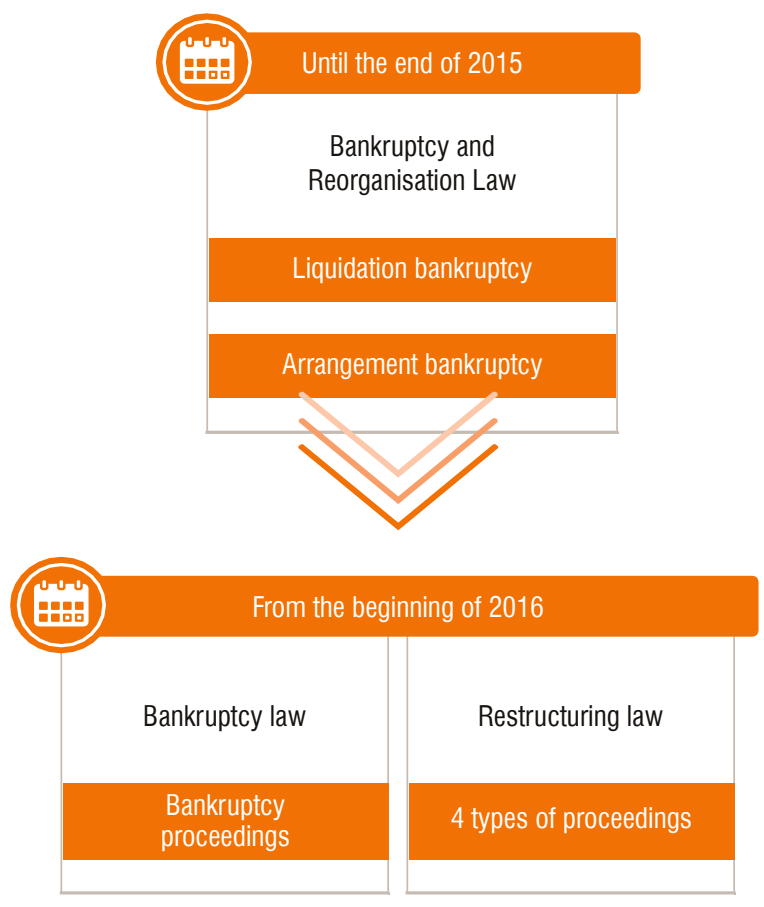

Source: own study.

In terms of the types or the course of proceedings, the legislative changes introduce a certain revolution in restructuring proceedings. And as is the case now, bankruptcy proceedings are to a large extent equal to liquidation bankruptcy before the change of the law, the sides of 
restructuring processes can use two totally different types of proceedings alongside arrangement procedures - on the approval of arrangement and sanative ones [Krajewski, Matuszak, Tokarski, 2017, p. 191].

The restructuring law changes totally the attitude towards an entrepreneur experiencing financial difficulties [Wieczerzyńska, 2015, p. 125]. It introduces four restructuring procedures, including sanative ones, and it changes the definition of bankruptcy of an entrepreneur.

The restructuring law with the bankruptcy law aim at creating a coherent system of regulations. A debtor potentially threated with bankruptcy and wanting to avoid it can attempt to restructure on their own initiative. However, it must be remembered that a company cannot be declared bankrupt during a restructuring procedure.

\section{Diagram 2. A 'decision tree' of bankruptcy and restructuring proceedings}

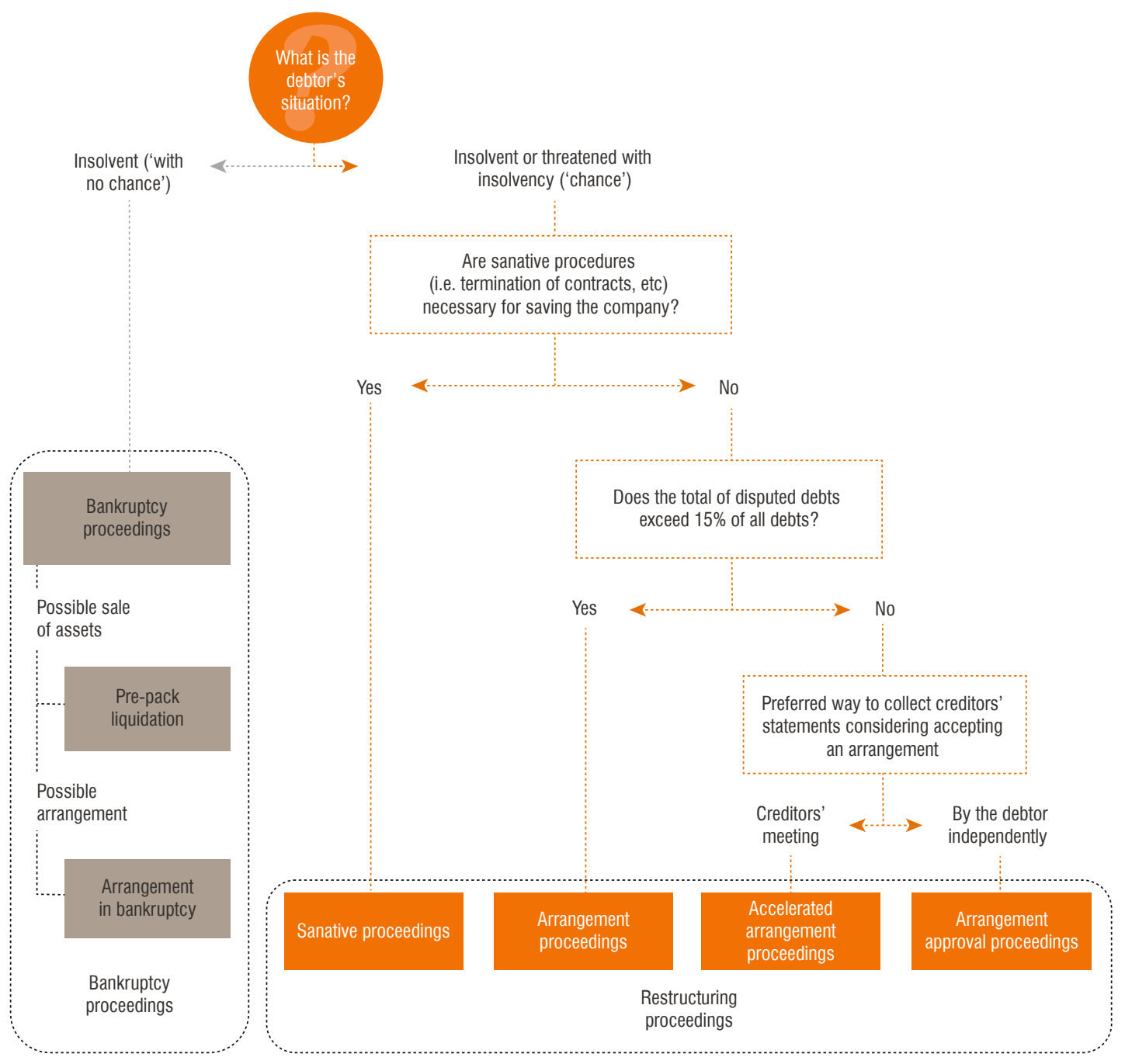

Source: PwC (2017), p. 8. 
The amended bankruptcy law focuses on entities threated with the continuation of activities which lead to their liquidation.

The objective of restructuring proceedings is to restructure a debtor's monetary liabilities, and in a sanative procedure also to restructure a debtor's employment and enterprise. Moreover, this solution allows an insolvent or threatened with insolvency entrepreneur to continue his or her activity, and it increases the chance to regain liabilities by creditors and preserve jobs and execute business contracts.

\section{The concept and types of restructuring proceedings in the Polish economy: an analysis of restructuring law regulations}

Restructuring proceedings are organised by means of legal and procedural relations activities of judicial and non-judicial authorities restructuring proceedings involving concerned entities. It aims at the protection of social and individual interests expressed in striving to avoid declaring bankruptcy of the debtor through enabling them restructuring by means of an arrangement entered into with creditors, and in the case of sanative procedure also by conducting sanative actions aiming at restoring the debtor's abilities to perform obligations while safeguarding the legitimate rights of creditors through using relevant provisions of law in factual circumstances. Restructuring proceedings by definition are of collective nature [Statement of Reasons, 2014, p. 1]. Its participants according to Article 65 paragraph 1 of the RL are: [Law of $15^{\text {th }}$ of May 2015]:

- the debtor;

- the debtor's personal creditor who is entitled to undisputed debt;

- the debtor's personal creditor who is entitled to disputed debt and who rendered their debt credible and was admitted to taking part in the case by a judge-commissioner.

Restructuring proceedings are conducted in relation to a company which is insolvent or threatened with insolvency [Kaczmarczyk, 2018, p. 70].

The subject of the proceedings is 'a restructuring case' (see Article 15 paragraph 1 of the $\mathrm{RL}$ and Article 342 paragraph 1 of the RL). 'A restructuring case' means a civil matter the subject of which is a comprehensive solution to the conflict of interests between the debtor and creditors and between creditors themselves in connection with the debtor's insolvency or a risk of insolvency in a way adopted by the debtor and a specified majority of creditors.

Restructuring proceedings consist of an organised sequence of activities. They are addressed to companies which are insolvent or threated with bankruptcy. The Treasury, self-government units, state-owned banks, insurance companies, reinsurance offices and investment funds are exempted from the possibility of using restructuring proceedings [Czerkas, Teisseyre, 2016, p. 39].

The aim of restructuring proceedings is to avoid the debtor's bankruptcy by enabling them to restructure by means of entering into arrangement with creditors, and in the case of 
a sanative procedure also by conducting sanative activities while safeguarding the legitimate rights of creditors [Kowalak, 2017, p. 73].

Public perception of a particular legal regulation and proceedings of restructuring is of crucial importance for conducting successful restructuring of an enterprise. Practice shows that declaring the debtor's bankruptcy itself repeatedly excludes any possibility of conducting a successful restructuring, whether it is bankruptcy with the possibility of concluding an arrangement or liquidation bankruptcy. Associating bankruptcy with ending business activity, insolvency and not being able to recover debts is so strong that in many cases creditors do not want to negotiate with the debtor. For those reasons, the draft assumes separating restructuring proceedings from stigmatising bankruptcy proceedings. For clear and transparent separation, restructuring proceedings are regulated by a separate law - the Restructuring Law.

As the new restructuring proceedings, we include the following:

- arrangement approval proceedings;

- accelerated arrangement proceedings;

- arrangement proceedings;

- sanative proceedings.

Restructuring proceedings differ in terms of the degree of involvement of a bankruptcy court in the course of individual proceedings and of interference in a debtor's assets matters. Basically, all of them relate to a debtor's liabilities being restructured [Pałys, p. 8].

Additionally, the fifth procedure can be distinguished, which is particular and different form the others, so called partial arrangement addressed only to selected creditors of a debtor, entered into in restructuring proceedings conducted according to general procedures in forecasts (it can be entered into as an element of a bigger arrangement, alongside it, like and as a separated arrangement, if it is enough for repairing a debtor's situation) [Likwidacja, 2015, p. 153].

A common characteristic of those procedures will be restructuring of the debtor's company - firstly, of their liabilities and also, to a varying degree, of their assets, the way of business management and employment [Famielec, Kożuch, 2018, p. 190]. Prescribed procedures are supposed to ensure that the form of restructuring will be selected to meet the needs of a specific enterprise in a specific financial situation. In all restructuring proceedings identical regulations will be applied concerning the scope of debt covered by the arrangement, arrangement suggestions, entering into and approval of the arrangement and its consequences and also the rules of its changing and cancelling.

Table 1. Restructuring proceedings set out in the Restructuring Law

\begin{tabular}{|l|l|}
\hline \multicolumn{1}{|c|}{ Type of proceedings } & \multicolumn{1}{c|}{ Main assumptions } \\
\hline $\begin{array}{l}\text { Arrangement } \\
\text { approval } \\
\text { proceedings }\end{array}$ & $\begin{array}{l}\text { - independent collection of creditors' votes by the debtor without the participation of the court } \\
\text { - active negotiations with creditors and presenting their results to the court } \\
\text { - the debtor independently selects a licensed advisor who verifies arrangement suggestions in legal and } \\
\text { formal terms }\end{array}$ \\
\hline $\begin{array}{l}\text { Accelerated } \\
\text { arrangement } \\
\text { proceedings }\end{array}$ & $\begin{array}{l}\text { - drawing up a list of receivables by the debtor } \\
\text { - convening the assembly of creditors by the court } \\
\text { - approval of debt under a simplified procedure }\end{array}$ \\
\hline
\end{tabular}




\begin{tabular}{|l|l|}
\hline Type of proceedings & \multicolumn{1}{c|}{ Main assumptions } \\
\hline $\begin{array}{l}\text { Arrangement } \\
\text { proceedings }\end{array}$ & $\begin{array}{l}\text { - drawing up a list of claims by the debtor } \\
\text { - convening the assembly of creditors by court } \\
\text { - approval of debt under a simplified procedure } \\
\text { - leaving control over the property to the debtor } \\
\text { - liabilities towards ZUS (the Social Insurance Institution) covered by an arrangement }\end{array}$ \\
\hline $\begin{array}{l}\text { Sanative } \\
\text { proceedings }\end{array}$ & $\begin{array}{l}\text { - the debtor or a creditor, and in specific cases an administrator, submits a request for the opening of } \\
\text { - sanative proceedings } \\
\text { - liabilities, assets and employment are subject to restructuring } \\
\text { - a judge commissioner manages and supervises proceedings }\end{array}$ \\
& $\begin{array}{l}\text { - assets) or sanative assets administrator (the debtor loses the right to manage assets) } \\
\text { - the court administrator or sanative assets administrator draws up a sanative plan together with the debtor } \\
\text { is suspended granted by the debtor expire and execution against assets included into the sanative assets } \\
\text { - a ban on encumbering assets in order to secure liabilities incurred before the opening of proceedings } \\
\text { - legal and administrative proceedings conducted only by the administrator } \\
\text { - a ban on terminating renting, leasing, insurance, loan, etc. contacts with the debtor }\end{array}$ \\
\hline
\end{tabular}

Source: Famielec, Kożuch (2018), p. 190; Kaczmarczyk (2018), pp. 71-72.

Table 2. Advantages and disadvantages of restructuring proceedings from the debtor's and creditor's perspective

\begin{tabular}{|c|c|}
\hline \multicolumn{2}{|c|}{ ARRANGEMENT APPROVAL PROCEEDINGS } \\
\hline Advantages & Disadvantages \\
\hline $\begin{array}{l}\text { - the possibility of an independent collection of creditors' votes } \\
\text { by the debtor without the participation of the court. The } \\
\text { debtor presents creditors with voting cards with the methods } \\
\text { of debt restructuring (arrangement suggestions). The votes } \\
\text { are collected in the written form without the necessary } \\
\text { participation of a notary public; } \\
\text { - the debtor remains entitled to manage their assets and } \\
\text { conduct the management's activities, including those of } \\
\text { ordinary management; } \\
\text { - proceedings are confidential at the pre-court stage, and the } \\
\text { court stage is very short. Proceedings allow minimalizing } \\
\text { a negative market message connected with a financial crisis; } \\
\text { - proceedings give an opportunity to negotiate individually } \\
\text { without the rigors of court proceedings and without security } \\
\text { of the debtor's property; } \\
\text { - the proceedings administrator becomes the implementation of } \\
\text { the arrangement administrator after its legal approval; } \\
\text { - proceedings are ideal for entering into a partial arrangement, } \\
\text { with financial creditors in particular. }\end{array}$ & $\begin{array}{l}\text { - the main disadvantage is the lack of protection of the } \\
\text { debtor's assets from debt recovery. In the arrangement } \\
\text { approval proceedings, regulations on security are not used, } \\
\text { therefore, an execution cannot be suspended, or seizure of } \\
\text { bank accounts cannot be cancelled. It means that until the } \\
\text { arrangement is approved, a creditor can collect receivables } \\
\text { without limitations. Only after the arrangement is approved } \\
\text { are execution proceedings suspended and is initiating an } \\
\text { execution unacceptable; } \\
\text { - creditors can also terminate contracts including financing } \\
\text { agreements and renting or lease agreements during the } \\
\text { proceedings; } \\
\text { additionally, selecting the arrangement administrator and } \\
\text { establishing the arrangement day have no influence on } \\
\text { the exemption of the debtor's board (of a member of the } \\
\text { board) from liability for damages. Execution of bankruptcy } \\
\text { application submitted by creditors is not stopped, either; } \\
\text { - a lack of trust between creditors and the administrator } \\
\text { selected by the debtor is also observed - the administrator is } \\
\text { often seen as the debtor's proxy pursuing their interest; } \\
\text { time is a kind of limitation in these proceedings because the } \\
\text { debtor has only three months from a fixed arrangement day } \\
\text { for collecting votes and preparing with the administrator an } \\
\text { application to court for approving the arrangement. If the } \\
\text { liabilities structure is distributed, the time can be too short } \\
\text { to obtain votes; } \\
\text { the capital majority required for approving the arrangement } \\
\text { amounts to } 2 / 3 \text { of creditors entitled to vote the arrangement } \\
\text { - in other restructuring proceedings this majority is calculated } \\
\text { by reference to the sum of voting creditors. Therefore, the } \\
\text { arrangement can be rejected when over } 1 / 3 \text { of creditors } \\
\text { will be passive or will vote against. It is negative for active } \\
\text { creditors that have reached an agreement with the debtor; }\end{array}$ \\
\hline
\end{tabular}




\begin{tabular}{|c|c|}
\hline \multicolumn{2}{|c|}{ ARRANGEMENT APPROVAL PROCEEDINGS } \\
\hline Advantages & Disadvantages \\
\hline & $\begin{array}{l}\text { - creditors do not possess means of appeal in the scope } \\
\text { of the list of receivables, which does not constitute an } \\
\text { enforcement order, either. They can only submit a written } \\
\text { reservation with respect to the compliance with law of the } \\
\text { independent process of collecting votes or indicating other } \\
\text { circumstances which may have an impact on the approval of } \\
\text { the arrangement. }\end{array}$ \\
\hline \multicolumn{2}{|c|}{ ACCELERATED ARRANGEMENT PROCEEDINGS } \\
\hline Advantages & Disadvantages \\
\hline $\begin{array}{l}\text { - as early as on the day of the proceedings opening the debtor } \\
\text { obtains assets protection in the form of the suspension of } \\
\text { execution proceedings concerning liabilities covered by the } \\
\text { arrangement by law, and their initiating after the opening of } \\
\text { the proceedings is unacceptable; } \\
\text { - execution proceedings concerning liabilities not covered by } \\
\text { the arrangement by law can be suspended for three months, } \\
\text { and a creditor secured by collateral by the debtor's assets } \\
\text { can after that period conduct an execution against security } \\
\text { (collateral) exclusively; } \\
\text { - a short period of the proceedings prevents stigmatising } \\
\text { the debtor in connection with conducting business with the } \\
\text { existing company with the label 'in restructuring'; } \\
\text { - the administrator can give an agreement to conduct activities } \\
\text { beyond the scope of ordinary management ex post, which } \\
\text { eliminates the risk of decision-making blockage in current } \\
\text { activities and of payment delays for contractors; } \\
\text { - creditors obtain the decision on accepting and approving the } \\
\text { arrangement much faster, therefore, they can benefit from the } \\
\text { arrangement or resume suspended execution proceedings } \\
\text { much faster. }\end{array}$ & $\begin{array}{l}\text { - pressure resulting from the short duration of the proceedings } \\
\text { - restructuring unclear for contractors and employees } \\
\text { accompanied by the fear with respect to their own situation } \\
\text { can result in their moving away from the debtor when their } \\
\text { need to obtain beneficial and reliable financial results inspiring } \\
\text { creditors' confidence in the arrangement is the greatest; } \\
\text { - a lack of the debtor's protection when the period of } \\
\text { suspended execution proceedings is over - creditors secured } \\
\text { by the debtor's assets can conduct an execution against } \\
\text { security (collateral), which is necessary for the debtor for } \\
\text { conducting activities; } \\
\text { - eliminating the institution of an objection to including a liability } \\
\text { in the list of liabilities, because of which creditors cannot } \\
\text { question its amount or omission; } \\
\text { - too long period of 'suspension' between a non-final decision } \\
\text { to close unsuccessful restructuring proceedings and } \\
\text { a declaration of bankruptcy. }\end{array}$ \\
\hline \multicolumn{2}{|c|}{ ARRANGEMENT PROCEEDINGS } \\
\hline Advantages & Disadvantages \\
\hline $\begin{array}{l}\text { - the fact that the management of a company should stay in the } \\
\text { debtor's hands and only in an exceptional situation the court } \\
\text { gives it to the administrator is an unquestionable benefit for } \\
\text { the debtor; } \\
\text { - the moment the arrangement proceedings are open, } \\
\text { executing proceedings concerning receivables covered by } \\
\text { the arrangement are suspended. New executions cannot be } \\
\text { initiated. It is undoubtedly a beneficial regulation, because } \\
\text { it allows debtors to conduct uninterrupted negotiations with } \\
\text { creditors aiming at negotiating an optimal method of debt } \\
\text { restructuring; } \\
\text { creditors have a real influence on the proceedings under the } \\
\text { board of creditors, which can be appointed by the judge- } \\
\text { commissioner both ex offcio and when requested by the } \\
\text { debtor or at least three creditors or a creditor or creditors } \\
\text { having al least one fifth of the sum of receivables in total. The } \\
\text { board is supposed to, among others, control the activities } \\
\text { of the court administrator and give consent to activities } \\
\text { which can be conducted only when allowed by the board of } \\
\text { creditors. The board of creditors also provides opinions when } \\
\text { requested by the judge-commissioner, court administrator or } \\
\text { the debtor. }\end{array}$ & $\begin{array}{l}\text { - arrangement proceedings are not initiated towards debtors } \\
\text { as often as accelerated arrangement proceedings and } \\
\text { sanative proceedings. Most likely it results from the fact that } \\
\text { the provisions concerning these proceedings do not predict } \\
\text { benefits which debtors are offered by other proceedings; } \\
\text { - arrangement proceedings cannot be conducted as fast as } \\
\text { (as assumed) accelerated arrangement proceedings, neither } \\
\text { do they ensure such possibilities of such deep restructuring } \\
\text { as sanative proceedings (e.g. withdrawal from unfavourable } \\
\text { contracts or making employees redundant). }\end{array}$ \\
\hline
\end{tabular}




\begin{tabular}{|c|c|}
\hline \multicolumn{2}{|c|}{ SANATIVE PROCEEDINGS } \\
\hline Advantages & Disadvantages \\
\hline $\begin{array}{l}\text { - inadmissibility of obtaining execution against the debtor's } \\
\text { assets included into sanative assets, also execution of } \\
\text { receivables not covered by the arrangement - including those } \\
\text { incurred after opening sanative proceedings and secured by } \\
\text { collateral; } \\
\text { - the possibility of withdrawing from contracts unfavourable } \\
\text { for the debtor regardless of the mode specified by them } \\
\text { to terminate a given contract earlier; } \\
\text { - the possibility of terminating employment contracts without } \\
\text { personal situation limitations, which enables rationalisation } \\
\text { of the employment structure and retaining staff necessary } \\
\text { for conducting activity of an enterprise (e.g. admissibility of } \\
\text { termination of employment contacts using pre-retirement } \\
\text { protection); } \\
\text { - the possibility of declaration of no effect of legal actions } \\
\text { undertaken by the debtor within one year before submitting } \\
\text { a sanative application, e.g. establishing securities on their } \\
\text { assets despite the lack of direct connection with the debtor } \\
\text { obtaining a benefit, thanks to which the assets of a sanated } \\
\text { entrepreneur is released from economically irrational } \\
\text { securities; } \\
\text { the possibility of introducing so called 'over-collateralisation', } \\
\text { i.e. a situation of posting collateral higher than } 150 \% \text { of } \\
\text { receivables on the sanative assets at the moment of providing } \\
\text { collateral, which allows rebalancing for individual creditors; } \\
\text { the possibility of selling the debtor's assets with executive } \\
\text { effect, i.e. without encumbrances, which facilitates selling } \\
\text { redundant assets. }\end{array}$ & $\begin{array}{l}\text { - inadmissibility of execution causes concerns relating } \\
\text { to cooperation with the debtor and forces solutions such as } \\
\text { a demand for early payments, which hinders business and } \\
\text { maintaining liquidity; } \\
\text { - loss of full control over an enterprise by limiting or taking } \\
\text { away management form the debtor; } \\
\text { - real inability to obtain new financing in the banking sector. }\end{array}$ \\
\hline
\end{tabular}

Source: Zimmerman., Filipiak (2018), pp. 23-31.

\section{Division criteria of restructuring proceedings in the Polish economy}

A. Hrycaj distinguishes the following division criteria of restructuring proceedings in the Polish economy [Hrycaj, 1995, pp. 7-9]:

- division in terms of the level of involvement on the side of bodies of the court;

- division according to subjective criteria;

- division according to the scope of the debtor's protection;

- division with reference to the debtor's limitations in assets management.

From the point of view of the level of involvement in the proceedings on the side of bodies of the court, there are proceedings conducted on the basis of a court decision to open proceedings and under the supervision of a judge-commissioner (accelerated arrangement proceedings, arrangement proceedings and sanative proceedings) and proceedings the main part of which is of out-of-court character - arrangement approval proceedings. However, arrangement approval proceedings cannot be classified as clearly and entirely out-of-court proceedings. It results from the fact that in these proceedings the role of the court is not limited only to examining the procedure of collecting votes and the content of the arrangement, but it 
is much more complex. From the moment of submitting an application for the approval of the arrangement, the proceedings are of court character. The submission of an application itself implies the necessity to initiate a number of activities by the court. In particular, according to Article 222 paragraph 1 of the RL, the court immediately informs using means of long distance communication, particularly by phone, fax or electronic mail, the founding body or the competent minister in charge of the State Treasury, who can submit an opinion to the court, about the submission of an application for the approval of the arrangement which concerns a government-owned corporation or a company wholly owned by the State Treasury. The lack of an opinion does not suspend the examination of the case. Moreover, the fact of submitting an application is announced (Article 222 paragraph 3 of the RL). According to Article 224 paragraph 1 of the RL, from the day of issuing a decision as to the approval of the arrangement to the day of its validation, the arrangement administrator exercises the powers of the court administrator. At this stage of the proceedings, until the day of the validation of the decision as to the approval of the arrangement, the provisions of Article 259 of the RL and Article 260 of the RL are used. Consequently, it must be stated that arrangement approval proceedings are divided into two stages. The first stage has the character of civil proceedings. It starts with a conclusion of an agreement with a person holding a licence of a restructuring advisor for playing the role of the arrangement advisor, and it ends with a successful submission of an application for the approval of the arrangement to the restructuring court. The second stage has the nature of court restructuring proceedings and it starts with a submission of an application for the approval of the arrangement, and it ends with the validation of the decision as to the approval of the arrangement or of the decision to reject the application or to discontinue proceedings.

From the point of view of the subjective scope, there are proceedings that can be conducted by the debtor in relation to whom the sum of the disputed debt entitling to voting for the arrangement does not exceed $15 \%$ of the sum of debt entitling to voting for the arrangement (arrangement approval proceedings, accelerated arrangement proceedings), and proceedings that can be conducted by the debtor in relation to whom the sum of the disputed debt entitling to voting for the arrangement exceeds $15 \%$ of the sum of debt entitling to voting for the arrangement (arrangement proceedings, sanative proceedings). Establishing the upper limit of $15 \%$ results from the necessity to ensure that in every situation the decision concerning entering into an arrangement can be taken by the required majority of creditors. In the situation when for entering into an arrangement it is crucial to obtain an acceptance of creditors holding at least $2 / 3$ of the sum of receivables owed to the voting creditors (Article 119 paragraph 1 of the RL), even the omission of all creditors with disputed debts (maximum 15\%) means that the decision can be taken by creditors with at least $50 \%$ of the sum of receivables owed to the voting creditors. In the proceedings belonging to the first group, a simplified procedure of creating a list of receivables is provided.

Using the scope of specified in the law measures designed to restructuring of the debtor's company as a division criterion, there are proceedings in which the scope of the debtor's 
protection is small (arrangement approval proceedings), proceedings in which the scope of the debtor's protection amounts to the protection against execution proceedings conducted by creditors (accelerated arrangement proceedings and arrangement proceedings), and proceedings which enable initiating activities allowing for deep and multidimensional restructuring of the debtor's enterprise (sanative proceedings).

Taking into account the division criterion of restructuring proceedings on grounds of the debtor's limitations in assets management, there are proceedings in which the debtor is not at all limited in assets management (arrangement approval proceedings), proceedings in which the debtor is limited in assets management by the necessity to obtain the court administrator's agreement to conduct activities beyond the scope of ordinary management (accelerated arrangement proceedings, arrangement proceedings), and proceedings in which the debtor has no right to manage assets (sanative proceedings).

The following relationship can be seen here: the bigger the scope of the debtor's entitlements, and as a consequence, the bigger scope of their protection, the bigger limitations in the scope of assets management. The debtor's protection is closely connected with limiting creditors' rights. Limiting the debtor in assets management does not constitute a sanction for infringement of creditors' rights, but it aims at guaranteeing that the protection granted to the debtor is not used inappropriately. At the out-of-court stage of arrangement approval proceedings, the debtor is by no means limited in assets management, but simultaneously does not receive any protection from execution or other activities conducted by creditors. Limiting the debtor in managing assets does not appear until the court stage of the arrangement approval proceedings after the court decides as to the approval of the arrangement. Then the administrator is given the power of the court administrator (Article 224 paragraph 1 of the RL), which means particularly that Article 39 paragraph 1 of the RL is used, according to which the debtor's activities beyond the scope of ordinary management require an approval of the court administrator under pain of nullity.

Simultaneously, as of the day of the issuing of the decision as to the approval of the arrangement by virtue of law execution, proceedings concerning receivables covered by arrangement by virtue of law, initiated before the day of the issuing, are suspended (Article 259 paragraph 1 of the RL in connection with Article 224 paragraph 2 of the RL), and the court, when requested by the debtor or proceedings administrator, can annul the seizure performed before the day of the decision issuing as to the approval of the arrangement in execution or securing proceedings concerning receivables covered by virtue of law by the arrangement, if it is necessary for continuing to run business (Article 259 paragraph 2 of the $\mathrm{RL}$ in connection with Article 224 paragraph 2 of the RL). After the day of the issuing of the decision as to the approval of the arrangement, it is also unacceptable to initiate execution proceedings and to enforce a decision to secure a claim or order securing a claim resulting from receivables covered by virtue of law by the arrangement (Article 259 paragraph 3 of the RL in connection with Article 224 paragraph 2 of the RL). According to Article 260 paragraphs 1 and 2 of the RL, a creditor with a receivable secured on the debtor's assets 
by a mortgage, a pledge, a registered pledge, a tax lien or maritime mortgage, can after the day of the issuing of the decision as to the approval of the arrangement conduct an execution only against the security (collateral). The court, when requested by the debtor of the arrangement administrator, can suspend execution proceedings as to liabilities not covered by virtue of law by the arrangement, if the execution concerns the security necessary for running an enterprise. In the accelerated arrangement proceedings and arrangement proceedings the scope of the debtor's security is identical. The difference lies in the moment of obtaining security. In accelerated arrangement proceedings, proceedings to secure claims are not conducted, which means the debtor does not obtain protection until the moment the court issues a decision on opening proceedings. It is an effect of Article 232 paragraphs 1 and 2 of the RL, according to which the court examines an application for opening accelerated arrangement proceedings at a closed-door hearing based only on the documents submitted together with an application within one week from its submission. Such a short term established by the legislator for examining an application for opening accelerated arrangement proceedings excludes the possibility of conducting proceedings to secure claims at this stage. In arrangement proceedings, in Article 270 paragraph 1 of the RL, the rule of examining an application at a closed-door hearing within the period of two weeks is used, however, the legislator decided that if there is need to schedule a trial, then an application is examined within six weeks (Article 270 paragraph 2). Such differences in the time and methods of examining an application for opening accelerated arrangement proceedings results from the diverse nature of grounds for excluding the possibility of opening proceedings. In opening proceedings for arrangement proceedings, the court must additionally verify whether the debtor has made plausible the ability to satisfy the costs of proceedings and liabilities resulting after its opening. The above-mentioned regulation also logically implies the ability to offer the debtor protection as early as at the stage of proceedings for opening arrangement proceedings introduced by the legislator. According to Article 268 paragraphs 1 and 2 of the $\mathrm{RL}$, in proceedings for opening arrangement proceedings, the court can secure the debtor's assets by appointing a temporary court administrator, suspending execution proceedings and cancelling the seizure of bank accounts. Also, in sanative proceedings, the debtor can obtain protection as early as at the stage of proceedings as to examination of the application for opening restructuring proceedings. The difference in sanative proceedings lies in the fact that in these proceedings far-reaching activities are included, which aim at restructuring the debtor's enterprise by partial of full implementation of a sanative plan during proceedings with the possibility of using instruments for the reduction of employment (Article 300 of the $\mathrm{RL}$ ) or withdrawal from reciprocal contracts (Article 298 paragraphs 1 and 2 of the RL). 


\section{Benefits and threats resulting from the multiplicity of restructuring proceedings}

The basic benefit resulting from the multiplicity of restructuring proceedings lies in the fact that for each debtor an optimal type of proceedings can be 'selected'.

An entrepreneur with less than 15\% of disputed debts can conduct arrangement approval proceedings, accelerated arrangement proceedings or sanative proceedings. Such an entrepreneur chooses arrangement approval proceedings when convinced that they can independently (with the help of the proceedings administrator) convince creditors to vote for an arrangement and at the same time do not need protection from execution. Accelerated arrangement proceedings will be chosen by such an entrepreneur who for various reasons is not sure that an independent collection of creditors' votes can be successful or who needs protection from enforcement of claims by creditors for some time.

An entrepreneur with more than $15 \%$ of dispute debts can conduct arrangement proceedings or sanative proceedings. Arrangement proceedings will be selected by such an entrepreneur who does not need particular possibilities of restructuring in the area of restructuring of employment, assets and contracts, and at the same time does not want to lose the management of their assets.

An entrepreneur, regardless of the sum of disputed debts, will select sanative proceedings when full protection from execution and using particular restructuring instruments are needed for restructuring their enterprise. In exchange for this protection, they will lose the management of their assets.

The basis threat resulting from the multiplicity of restructuring proceedings is connected with the possibility of conducting first accelerated arrangement proceedings or arrangement proceedings, and then sanative proceedings opened on the basis of a simplified application for opening sanative proceedings (Article 328 paragraphs 1 and 2 of the RL).

Due to the change of the proportion of disputed and undisputed debts, conducting first accelerated arrangement proceedings and then arrangement proceedings is possible. Such a threat should not be neglected, because, as it was pointed out before, restructuring proceedings not only exclude the ability to conduct execution against the debtor by creditors in a specified scope, but they also exclude the ability to declare bankruptcy.

However, it should not be forgotten that both opening and continuing of restructuring proceedings depends on the court's decision, and it must take into account creditors' interests. According to the Article 8 paragraph 1 of the RL, the court rejects opening restructuring proceedings if it is detrimental to creditors. Creditors' detriment is even more probable when the debtor submits another application for opening restructuring proceedings, which obliges the court to conduct particularly detailed examination of the legitimacy of an application under the negative premise for opening proceedings indicated in Article 8 paragraph 1 of the RL. If the circumstances specified by Article 8 paragraph 8 of the RL occurred after the opening 
of restructuring proceedings, then, according to Article 325 paragraph 1 point 1 of the RL, the court should discontinue the proceedings. The court can also discontinue restructuring proceedings when the circumstances of the case, and the debtor's behaviour in particular, indicate that the proceedings will not be completed (Article 325 paragraph 2 of the RL). It seems that the mentioned regulations properly protect the interest of creditors, who at every stage of proceedings can indicate the basis for their discontinuation.

\section{Statistics of restructuring proceedings in the Polish economy in the years 2016-2018}

Analysing the effects of the introduction of restructuring law, two effects are worth distinguishing [Zimmerman, Filipiak, 2018]. On the one hand, a displacement effect occurred, that is using restructuring proceedings by those companies which in the status quo conditions would have to go through a bankruptcy process. On the other hand, a creation effect occurred, as the new law encouraged attempting to restructure many companies which, without this law, would not have decided to negotiate with their creditors. The reason for introducing the new regulations was exactly to encourage faster restructuring of companies which do not want to enter the bankruptcy process. Separating those effects is not easy and it requires an econometric analysis, whereby it is estimated that out of 585 proceedings, about $40 \%$ (almost 250) are the effect of displacement and about $60 \%$ of the creation effect (over 330).

An analysis of the number and structure of restructuring and bankruptcy proceedings in the Polish economy is shown in Tables 3-5.

Table 3. Number of bankruptcy proceedings in the Polish economy in the years 2013-2018

\begin{tabular}{|l|c|c|c|c|c|c|}
\hline \multicolumn{7}{|c|}{ Number of bankruptcy proceedings } \\
\hline Month & 2018 & 2017 & 2016 & 2015 & 2014 & 2013 \\
\hline January & 54 & 50 & 49 & 60 & 60 & 82 \\
\hline February & 48 & 46 & 42 & 62 & 65 & 76 \\
\hline March & 62 & 41 & 63 & 83 & 63 & 71 \\
\hline April & 49 & 45 & 55 & 61 & 62 & 84 \\
\hline May & 42 & 43 & 51 & 75 & 78 & 67 \\
\hline June & 59 & 47 & 49 & 61 & 74 & 86 \\
\hline July & 47 & 58 & 53 & 67 & 81 & 89 \\
\hline August & 50 & 55 & 38 & 64 & 61 & 67 \\
\hline September & 33 & 56 & 61 & 44 & 71 & 68 \\
\hline October & 65 & 50 & 53 & 56 & 82 & 79 \\
\hline November & 52 & 54 & 44 & 57 & 49 & 63 \\
\hline December & 54 & 46 & 48 & 60 & 61 & 56 \\
\hline Total & $\mathbf{6 1 5}$ & $\mathbf{5 9 1}$ & $\mathbf{6 0 6}$ & $\mathbf{7 5 0}$ & $\mathbf{8 0 7}$ & $\mathbf{8 8 8}$ \\
\hline
\end{tabular}

Source: The Central Economic Information Bureau. Retrieved from: www.coig.com.pl/2018-upadlosci-firm_grudzien.php [accessed: 14.01.2019]. 
In 2017 in the Court and Commercial Gazette bankruptcies concerning 591 companies were published. In 2016, 606 bankruptcies were announced. If those figures are compared with the numbers of bankruptcies in previous years, a decreasing trend is observed.

For specifying a real trend, it must be taken into account that from January 2016 companies experiencing serious problems with liquidity and paying liabilities were able to initiate restructuring proceedings instead of declaring bankruptcy. 465 such proceedings in 2018 with 348 in 2017 and 212 in 2016.

Table 4. Number of restructuring proceedings in the Polish economy in the years 2016-2018

\begin{tabular}{|l|c|c|c|}
\hline \multicolumn{3}{|c|}{ Number of restructuring proceedings } \\
\hline January & 2016 & 2017 & 2018 \\
\hline February & - & 24 & 37 \\
\hline March & 2 & 29 & 46 \\
\hline April & 12 & 35 & 33 \\
\hline May & 10 & 23 & 37 \\
\hline June & 13 & 21 & 48 \\
\hline July & 18 & 24 & 29 \\
\hline August & 18 & 33 & 48 \\
\hline September & 28 & 29 & 36 \\
\hline October & 31 & 27 & 52 \\
\hline November & 19 & 32 & 34 \\
\hline December & 31 & 32 & 32 \\
\hline Total & 30 & 39 & $\mathbf{4 6 5}$ \\
\hline
\end{tabular}

Source: The Central Economic Information Bureau. Retrieved from: www.coig.com.pl/2018-restrukturyzacje-firm_grudzien.php [accessed: 14.01.2019]

When it comes to the type of procedures, debtors most often decided on restructuring within the frames of accelerated arrangement proceedings - 134 proceedings in 2016, 198 in 2017 and 294 in 2018.

Table 5. Type of restructuring procedure in the Polish economy in the years 2016-2018

\begin{tabular}{|l|c|c|c|c|c|c|}
\hline \multirow{2}{*}{ Type of restructuring procedure } & \multicolumn{2}{|c|}{2016} & \multicolumn{2}{c|}{2017} & \multicolumn{2}{c|}{2018} \\
\cline { 2 - 8 } & $\begin{array}{c}\text { Number of } \\
\text { procedures }\end{array}$ & $\begin{array}{c}\text { Percentage } \\
\text { structure }\end{array}$ & $\begin{array}{c}\text { Number of } \\
\text { procedures }\end{array}$ & $\begin{array}{c}\text { Percentage } \\
\text { structure }\end{array}$ & $\begin{array}{c}\text { Number of } \\
\text { procedures }\end{array}$ & $\begin{array}{c}\text { Percentage } \\
\text { structure }\end{array}$ \\
\hline Accelerated arrangement proceedings & 134 & 63.21 & 198 & 56.90 & 294 & 63.23 \\
\hline Sanative proceedings & 48 & 22.64 & 87 & 25.00 & 121 & 26.02 \\
\hline Arrangement proceedings & 30 & 14.15 & 53 & 15.23 & 46 & 9.89 \\
\hline Arrangement approval proceedings & - & - & 10 & 2.87 & 4 & 0.86 \\
\hline Total & $\mathbf{2 1 2}$ & $\mathbf{1 0 0 . 0 0}$ & $\mathbf{3 4 8}$ & $\mathbf{1 0 0 . 0 0}$ & $\mathbf{4 6 5}$ & $\mathbf{1 0 0 . 0 0}$ \\
\hline
\end{tabular}

Source: Calculations of authors based on The Central Economic Information Bureau. Retrieved from: www.coig.com.pl/2018-restrukturyzacje-firm_grudzien.php [accessed: 14.01.2019] 
The presented data show that in the researched period the number of restructuring procedures increased, but, apart from 2018, the number of bankruptcy procedures decreased. It is disturbing that in 2018 the numbers of both bankruptcy and restructuring procedures increased despite Poland's good economic situation.

\section{Summary}

The problem of the accuracy of choice between the liquidation of an enterprise and its restructuring is one of the main topics of interest for practitioners and theorists dealing with the bankruptcy of enterprises.

Moving from the liquidation to the restructuring model of bankruptcy requires changes adopted by lawyers, economists, managers, business representatives and representatives of the State because they create a group of interest whose main objective, in this case, is to conduct skilfully a bankruptcy process which leads to paying liabilities to creditors with simultaneous preserving a good economic and financial situation of an enterprise. Only meeting these conditions, a restructuring agent becomes a real guide in a difficult reorganisation process, who creates new patterns of effective behaviours in favour of both a bankrupt enterprise and its creditors.

New regulations for entities which found themselves in a difficult financial situation have been introduced in Poland. Following the provisions of the New Chance Policy, debt restructuring and repair procedures which, depending on the financial and economic situation of an entrepreneur, should ensure the best solutions with simultaneous respect for the creditors' interests have been introduced in the legal system.

Therefore, a new regulation - the restructuring law - manifests a new approach to a failure in economic activity and insolvency. The aim of the European Commission's recommendation is to ensure that profitable companies in a difficult financial situation, regardless of the place of their residence in the area of the Union, have access to the national framework of bankruptcy proceedings enabling restructuring at an early stage in order to prevent their insolvency and ensure maximisation of value for creditors, employees, owners and for the whole economy. The objective of the recommendation is also to enable honest entrepreneurs declared bankrupt to use a second chance at the territory of the EU.

\section{References:}

\section{Legal acts:}

1. Ustawa z dnia 15 maja 2015 r. - Prawo restrukturyzacyjne, (Dz.U. z 2015 r. poz. 978) [Act on the Restructuring Law as of 15 May 2015, Journal of Laws No. 978, (2015)].

2. Ustawa prawo upadłościowe z dnia 15.05.2015 r. (Dz.U. z 2015 r. poz. 233) [Bankruptcy Law of $15^{\text {th }}$ May 2015 (Journal of Laws of 2015, item 233)] 


\section{Compact publications:}

1. Altman, E. I, Hotchkiss, E. (2007). Trudności finansowe a upadłość firm [Financial Difficulties and Company Bankriptcy] Warszawa: Cedewu.

2. Banasik, P., Morawska, S. (2016), Corporate restructuring. The directions of legislative changes. Ekonomika i Organizacja Przedsiębiorstw, No. 1.

3. Czerkas, K., Teisseyre, B. (2016). Restrukturyzacja zadłużenia przedsiębiorstw. Od ugód bilateralnych do postępowań restrukturyzacyjnych i upadłościowych [Corporate Debt Restructuring. From Bilateral Settlements to Restructuring and Bankruptcy Proceedings] Gdańsk: ODDK.

4. Famielec, J., Kożuch, M. (2018). Restrukturyzacja sektorów gospodarki i przedsiębiorstw wybrane zagadnienia [Restructuring of Sectors of Economy and Enterprises, Selected Issues]. Kraków: UE.

5. Hrycaj, A. (2015). Cztery postępowania restrukturyzacyjne [Four Restructuring Proceedings]. Restructuring Consultant, No. 5.

6. Hrobiowski, J. (2016). Efektywność procedur insolwencyjnych- refleksje na podstawie wyników badań aktów sądowych oraz próba nakreślenia perspektyw [Effectiveness of Insolvency Procedures - Reflections on Basis of Court Records Analysis and an Attempt to Map Prospects]. Biuletyn PTE, No. 4.

7. Kaczmarczyk, A. (2018). Koszty w postępowaniu restrukturyzacyjnym i upadłościowym $\mathrm{w}$ świetle regulacji prawnych [Costs of restructuring and bankruptcy in terms of balance sheet and tax law]. Prace naukowe Uniwersytetu Ekonomicznego we Wrocławiu, No. 524, p. 70.

8. Krajewski, J., Matuszak, M., Tokarski, A. (2017). Wpływ czynników makroekonomicznych na skalę i dynamikę upadłości przedsiębiorstw [Impact of Macroeconomic Factors on the Scale and Dynamics of Business Insolvency]. [In:] Inwestor, przedsiębiorca, państwo. Współtwórcy gospodarki innowacyjnej. Przedsiębiorczość i Zarządzanie. R. Pastusiak, P. Trippner (Eds.), Vol. XVIII, paper 7, part 2.

9. Kowalak, R. (2017). Koszty restrukturyzacji w świetle prawa bilansowego i prawa restrukturyzacyjnego [The costs of restructuring processes in accounting law and act of restructuring], Prace Naukowe Uniwersytetu Ekonomicznego we Wrocławiu, No. 480, p. 73.

10. Kowalak, R. (2017). Rola systemów wczesnego ostrzegania w procesie podejmowania decyzji o restrukturyzacji przedsiębiorstwa [The role of early warning systems in decision making about the restructuring processes]. Prace Naukowe Uniwersytetu Ekonomicznego we Wrocławiu, No. 472.

11. Kowalewska, A. (2011). Druga szansa dla przedsiębiorców. Raport z badań [Second chance for entrepreneurs. Research report]. Warszawa: PARP.

12. Likwidacja i upadłość podmiotów gospodarczych: aspekty bilansowe i podatkowe [Liquidation and Bankruptcy of Economic Entities: Balance and Tax Aspects] (2015). Warszawa: Accountants Association in Poland.

13. Mączyńska, E. et al. (2008). Bankructwa przedsiębiorstw. Wybrane aspekty instytucjonalne [The bankruptcy of enterprises and its institutional aspects]. Warszawa: OW SGH.

14. Mączyńska, E. et al. (2010). Cykle życia i bankructwa przedsiębiorstw [The cycle of life and bankruptcy of enterprises]. Warszawa: OW SGH, pp. 433-434.

15. Mączyńska, E. et al. (2015). Efektywność procedur upadłościowych. Bankructwa przedsiębiorstw katharsis i nowa szansa [The Effectiveness of the bankruptcy proceedings. The bankruptcy of the enterprises, catharsis and the new chance]. Warszawa: OW SGH. 
16. Miodek, P., Speer, Ł (2015). Przedsiębiorstwo w stanie upadłości -na przykładzie wytycznych „polityki nowej szansy” [An Enterprise in Liquidation Illustrated with the Example of “the New Chance Policy"]. Enterprise of the Future, No. 1(22).

17. Morawska, S., Staszkiewicz, P. (2016). Skuteczność prawa upadłościowego - wyniki badań empirycznych [Bankruptcy Law Efficiency - Results of Empirical Research]. PTE Bulletin, No. 4(75).

18. Ocena skutków regulacji z dnia 9-05-2014 Ministerstwo Sprawiedliwości [Evaluation of effects of regulations of $9^{\text {th }}$ May 2014 Ministry of Justice] (Warszawa 2014), p. 1. Retrieved from: www.ms.gov.pl/pl/restrukturyzacja-i-upadlosc/

19. Pałys, J. (2015). Nowe procedury restrukturyzacji przedsiębiorstw [New Procedures of Corporate Restructuring]. Accounting, No 8.

20. Prawo sprzyjające realizacji Polityki II szansy w Polsce. Rekomendacje zmian [The law favourable towards the implementation of the Second Chance Policy in Poland. The recommendation of changes] (2011). Warszawa: PARP.

21. Piasecki, B. (2012). Upadek małych firm. Symptomy i strategie wczesnego ostrzegania [Bankruptcy of Small Companies. Symptoms and Early Warning Strategies]. Łódź: Łódź Univeristy.

22. Polityka nowej szansy [New Chance Policy] (2015). Warszawa: Ministry of Economy.

23. Rekomendacje Zespołu Ministra Sprawiedliwości ds. Nowelizacji Prawa upadłościowego $i$ Naprawczego [Reccomendations of the Group of the Minister of Justice for Bankruptcy Law and Reorganisation Law Amendment] (2012). Warszawa: Ministry of Justice Retrieved from: www.ms.gov.pl/pl/restrukturyzacja-i-upadlosc/ [accessed: 10.12.2012].ini

24. Ropęga, J. (2017). Wsparcie przedsiębiorstwa w kryzysie oraz ponownego rozpoczęcia działalności gospodarczej w aspekcie polityki nowej szansy [Support of business in crisis and fresh start in the context of the New Chance Policy]. Prace Naukowe Uniwersytetu Ekonomicznego we Wrocławiu, No. 487.

25. Tokarski, A., Tokarski, M. (2018). The Influence of the Macroeconomic Factors on the Scale and Dynamics of the Bankruptcy of Enterprises in the Polish Economy in the Years 2000-2015. Transformations in Business and Economics, Vol. 17, No. 2AQ (44A).

26. White, M. (1989). The corporate bankruptcy decision. Journal of Economic Perspectives, Vol. 3.

27. Wieczerzyńska, B. (2015). Prawo restrukturyzacyjne - nowoczesna regulacja zapobiegająca likwidacji przedsiębiorstwa dłużnika [Restructuring Law - Modern Regulation Preventing Liquidation of a Creditor's Company]. [In:] Wybrane aspekty mezo i mikro konkurencyjności [Selected Aspects of Mezo and Micro Competitiveness], M. Olczyk (Ed.). Gdańsk: Politechnika Gdańska. Wydział Zarządzania i Ekonomii.

28. Wieczerzyńska, B. (2015). Prawo restrukturyzacyjne - potrzeba i ocena regulacji, [Restructuring Law - the Need and Evaluation of Regulations]. Studia Ekonomiczne, Prawne i Administracyjne, No. 2.

29. Upadłości i restrukturyzacje w Polsce. Wskaźniki prognozujące trudności finansowe oraz wybrane skutki zmian w przepisach z zakresu upadłości i restrukturyzacji [Bankruptcy and Restructuring in Poland. Indicators Forecasting Financial Difficulties and Selected Effects of Changes in Bankruptcy and Restructuring Regulations] (2017). Warszawa: PwC. 
30. Uzasadnienie do projektu Prawo restrukturyzacyjne [Statement of Reasons for Restructuring Law] (2014). Warszawa: Ministerstwo Sprawiedliwości. Retrieved from: www.ms.gov.pl/pl/ restrukturyzacja-i-upadlosc [accessed: 9.05.2014].

31. Zimmerman, P., Filipiak, P. (2018). Restrukturyzacja $w$ Polsce w latach 2016-2017 [Restructuring in Poland in the Years 2016-2017]. Warszawa: SPOTDATA.

\section{Internet materials:}

1. www.coig.com.pl/2018-upadlosci-firm_grudzien.php

2. www.coig.com.pl/2018-restrukturyzacje-firm_grudzien.php 